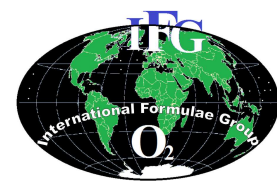

Original Paper

http://indexmedicus.afro.who.int

\title{
Determination of critical period for weed control in intensive and non-intensive sugarcane (Saccharum officinarum L., Poaceae) production systems in center Côte d'Ivoire
}

\author{
Koffi Badou Jérémie KOUAMÉ ${ }^{1 *}$, Youppo Barthélémy OREGA ${ }^{1}$, \\ Yao Antoine TOURÉ ${ }^{2}$ and Kouabenan $\mathrm{ABO}^{1}$ \\ ${ }^{I}$ Institut National Polytechnique Félix Houphouët-Boigny, Département de Formation de Recherche \\ Agriculture et Ressources Animales, BP 1313 Yamoussoukro, Côte d'Ivoire. \\ ${ }^{2}$ Institut National Polytechnique Félix Houphouët-Boigny, Ecole Supérieure d'Agronomie, BP 1313 \\ Yamoussoukro, Côte d'Ivoire. \\ *Corresponding author; E-mail: jeremie.kouame@gmail.com; je.badou@yahoo.fr \\ Tél.: +22549999462
}

\begin{abstract}
Field experiments were conducted in Zuenoula and Yamoussoukro for determining Critical Period for Weed Control (CPWC) in sugarcane. The treatments consisted in two sets of weed interference. In the first set, the crop was kept weed-free until 31, 61, 92, 123 days after planting (DAP) in Zuenoula and until 32, 69, 98 and 162 DAP in Yamoussoukro. In the second set, weeds were permitted to grow within the crop until the above-mentioned DAP. The CPWC was determined for 5, 10, 15 and 20\% acceptable yield loss levels by fitting Logistic and Gompertz nonlinear equations to relative yield data. In both locations, increasing the duration of weed interference decreased sugarcane yield significantly. In Zuenoula, the CPWC was from 28 to 117, 30 to 93, 32 to 75 and 34 to 59 DAP to prevent yield losses of 5, 10, 15 and 20\%, respectively. In Yamoussoukro, the CPWC ranged from 38 to 163, 39 to 112, 40 to 99 and from 40 to 91 DAP to prevent yield losses of 5, 10, 15 and 20\%, respectively. Results suggest weed control between 28 and 117 DAP in Zuenoula and between 38 and 163 DAP in Yamoussoukro to provide maximum yield.

(C) 2014 International Formulae Group. All rights reserved.
\end{abstract}

Keywords: Weed interference, Gompertz, Logistic, weed control, yield.

\section{INTRODUCTION}

Weeds are major constraints to sugarcane production. Weeds, primarily, reduce yield and sucrose content in sugarcane due to their competition with the crop for limited resources such as light, soil water and soil nutrients. For example, pigweed is a luxuriant extractor of soil nitrogen that causes nitrate deficiencies in the sugarcane plant.
Khan et al. (2004) reported that cane yield is reduced to the extent of $20-25 \%$ due to weed infestation. Secondly, weeds host pathogens and nematodes. Specifically, weedy grasses serve as alternate hosts and reservoirs for viruses, and they harbor insects that carry diseases to sugarcane. Similarly, rats find shelter in weedy fields. 
They also impose other losses on growers, millers, and surrounding communities. Heavy weed infestation hinders sugarcane harvesting by adding unnecessary harvesting expenses (Cheema et al., 2010). Field workers may be injured by weeds with spiny or thorny protrusions, burs, or needles that penetrate the skin. Examples include starbur (Acanthospermum Schrank.), spiny amaranth (Amaranthus spinosus L.), itchgrass (Rottboellia cochinchinensis (Lour.) Clayton), smooth prickly poppy (Argemone glauca (Nutt. ex Prain) Pope), and other weedy species with burs or spines. Some weeds may cause allergies in some workers resulting in lost productivity. As a result, weeds may reduce harvesting efficiency by $5-20 \%$ and excessive weeds may cause some fields to be abandoned (Dudley et al., 2008). Unsuccessful control of guinea grass and vines, for example, can lead growers to destroy and replant some fields of sugarcane.

Consequently, weed control prior to crop canopy spread is crucial. Integrated weed management (IWM) involves a combination of cultural, mechanical, biological, genetic, and chemical methods for effective and economical weed control (Swanton and Weise, 1991). The principles of IWM should provide the foundation for developing optimum weed control systems and efficient use of herbicides. The critical period for weed control (CPWC) is a key component of an IWM program. It is a period in the crop growth cycle during which weeds must be controlled to prevent yield losses. Swanton and Weise (1991) defined the CPWC as the time interval when it is essential to maintain a weed-free environment to prevent crop yield loss. Knezevic et al. (2002), have described the CPWC as a "window" in the crop growth cycle during which weeds must be controlled to prevent unacceptable yield losses. Therefore, interference from weeds before or after the CPWC will not result in unacceptable reductions in yield. The CPWC is useful for making decisions on the need for weed control and the timing of this weed removal. Determining the appropriate timing of weed control tactics is valuable in developing integrated weed management systems (Rajcan and Swanton, 2001; Knezevic et al., 2002) and has been the subject of extensive research in agronomic crops (Zimdahl, 2004). The CPWC is determined by characterizing functional relationships between two separately measured competition components: crop yield as a function of the duration of weed interference to identify the beginning of CPWC, and crop yield as a function of the duration of the weed-free period to identify the end of CPWC.

Determining the CPWCs in intensive and non-intensive conditions will provide better understanding of weeds sustainable management in sugarcane. For that reason, our objectives were to determine the CPWC in those two production systems.

\section{MATERIALS AND METHODS}

\section{Sites description}

Field experiments were conducted in 2001-2002 at the Agricultural Integrated Unit of Sucrivoire Zuenoula (Commercial sugarcane fields of an Ivorian Sugar Company) and in 2010-2011 at the National School of Agronomy in Yamoussoukro, in the center of Côte d'Ivoire. In Zuenoula, the soil type was sandy clay loam, moderately desatured, with an acid $\mathrm{pH}$. At the experimental farm of National School of Agronomy, the soil type was sandy with $0.6 \%$ organic matter. The value of $\mathrm{pH}$ was 5.3. Carbon and nitrogen contents of the soil were, respectively $1.2 \%$ and $0.10 \%$ while the $\mathrm{C} / \mathrm{N}$ ratio was of $12 \%$. At the adsorption complex's level, the cation exchange capacity (CEC), total amount of charges that can be held in 
exchangeable form, the contents of ions $\mathrm{Ca}^{2+}$, $\mathrm{Mg}^{2+}, \mathrm{K}^{+}$and $\mathrm{Na}^{+}$were, respectively, 8.72 meq/100 g, de 1.722 meq/100 g, 0.801 $\mathrm{meq} / 100 \mathrm{~g}, 0.225 \mathrm{meq} / 100 \mathrm{~g}$ and 0.096 meq/100 g. The Fe, Mn, $\mathrm{Cu}$ and $\mathrm{Zn}$ contents were, respectively, 437 ppm, 126 ppm, 2 ppm and $1 \mathrm{ppm}$.

\section{Experimental design and procedures}

A randomized complete block design was used with four replications in 2001-2002 and 3 replications in 2010-2011. In 2010-2011 each plot was composed of three inter-furrows of $1.5 \mathrm{~m}$ and $4.2 \mathrm{~m}$ width (1.5 meter between furrows). The plot's area was $18.9 \mathrm{~m}^{2}(4.5 \mathrm{~m} \mathrm{x}$ $4.2 \mathrm{~m})$. In 2001-2002 each plot was composed of four furrows (1.5 meter between furrows) of $5 \mathrm{~m}$ long. The plot's area was $22.5 \mathrm{~m}^{2}(4.5$ $\mathrm{m} \times 5 \mathrm{~m}$ ). Thirty subplots were carried out in 2010-2011 and forty in 2001-2002. Two sets of treatments were imposed to represent both increasing duration of weed interference and the length of the weed-free period measured after planting. The first set of treatments established four levels of increasing duration of weed interference by delaying weed control from the time of crop planting up to predetermined dates after planting (weedy up to $31,61,92,123$ days after planting (DAP) in 2001-2002 and up to 32, 69, 98 and 162 DAP in 2010-2011) at which weed control was initiated and maintained for the remainder of the growing season. The second set of treatments established four levels of increasing length of the weed-free period by maintaining weed control from the time of crop planting up to the above-presented crop growth stages before subsequently emerging weeds were left uncontrolled for the remainder of the season. In addition, season long weedy and weed-free controls were included. Naturally occurring weed populations were used in trials. Weeds were removed by hand pulling and hoeing.

\section{Cultural management practices}

In Yamoussoukro, land preparation consisted in ploughing and harrowing. First ploughing was made on the $13^{\text {th }}$ of May 2010 followed by the harrowing on the $19^{\text {th }}$ May 2010. A second ploughing was carried out on the $4^{\text {th }}$ of July 2010 with a harrowing the same day. The furrows were made with hoes on the $16^{\text {th }}$ July 2010. Planting intervened on the $17^{\text {th }}$ July 2010 in single rows at $1.5 \mathrm{~m}$ spacing. The cuttings of variety $C_{O} 997$ (from Sucrivoire Zuenoula) were planted in plant cane cycle. There was no previous cropping; sugarcane was planted after a savannah fallow of 5 years.

In Zuenoula, on the other side, at the experimental site, located at the plot C 57, land preparation consisted in ploughing and making the furrows. Fertilizers, NPKSMg (18.5-9-24-2.5-2), applied at about one month and half after planting, were used at the rate of $650 \mathrm{~kg} / \mathrm{ha}(\mathrm{N}: 120.25 \mathrm{~kg} / \mathrm{ha}, \mathrm{P}: 58.5 \mathrm{~kg} / \mathrm{ha}, \mathrm{K}$ : $156 \mathrm{~kg} / \mathrm{ha}, \mathrm{S}: 16.25 \mathrm{~kg} / \mathrm{ha}$ and $\mathrm{Mg}: 13 \mathrm{~kg} / \mathrm{ha}$ ). Water was applied by irrigation reel sprinkler to the plot area throughout the crop growing season. Amount of irrigation was adjusted to meet crop water needs. The irrigation brought $613 \mathrm{~mm}$ to the sugarcane while the rainfall brought $501.04 \mathrm{~mm}$ that gives a total water supply of $1114.04 \mathrm{~mm}$. Planting was done on the $1^{\text {st }}$ October 2001 in single rows at $1.5 \mathrm{~m}$ spacing. The cuttings of the variety Co 997 were planted in plant cane cycle. The previous cropping was sugarcane.

\section{Weed and crop measurements}

In Zuenoula, an inventory was made first and it was followed by rating the abundance-dominance of main species regarding the sampling area. The scale to rate abundance-dominance is the one used by Le Bourgeois (1993). This scale is an adaptation to Braun-Blanquet (1932) (Table 1). 
In Yamoussoukro, two quadrats of 1 $\mathrm{m}^{2}$ were placed in the two inter-furrows within each experimental plot. At the day of each weed removal floristic studies were carried out to identify all the weeds of the plot in the sampling areas of each subplot. Secondly, weeds were harvested from the sampling areas. At each harvest, weeds were clipped at the soil surface, and dried at $70{ }^{\circ} \mathrm{C}$ for 48 hours to constant moisture content to obtain a measure of aboveground dry weed biomass. Final sugarcane harvest dates were the $20^{\text {th }}$ of June 2002 and the $18^{\text {th }}$ June 2011. In 2002, irrigation was stopped 1 month before cane harvest. For quantification of yield in both experiments, plants in the 2 central rows in each plot were harvested by hand. In Yamoussoukro, at the end of growing cycle, the weeds of the set of weed-free were harvested in the two 1 square meter quadrats on the $2^{\text {nd }}$ of June 2011 air-dried and weighted on the $8^{\text {th }}$ of July 2011. The end-of-season weed total biomass for the weed-free treatments was determined.

\section{Data analysis}

Yield data of individual plots were computed as the percentage of their corresponding weed-free plot yields. Relative yield data were subjected to analysis of variance with the use of the PROC MIXED function of Statistical Analysis System (SAS), to assess the effect of the length of the weedfree period and increasing duration of weed interference on relative sugarcane yields (Knezevic et al., 2002). The statistical significance of treatment was evaluated at $5 \%$ level of probability. Nonlinear regression analyses with the PROC NLMIXED function of SAS were used to estimate the relative yield of sugarcane as a function of increasing duration of weed interference or as a function of the length of the weed-free period, according to the procedure outlined by
Knezevic et al. (2002). A three-parameter logistic equation, proposed by Hall et al. (1992) and modified by Knezevic et al. (2002) was used to describe the effect of increasing duration of weed interference on relative yield. The following logistic equation was used:

$Y=\left(\left(\frac{1}{e^{c \cdot(x-d)}+f}\right)+\left(\frac{f-1}{f}\right)\right) * 100$

where $\mathrm{Y}$ is the relative yield, $\mathrm{x}$ is the duration of weed interference measured from the time of sugarcane planting in DAP, $d$ is the point of inflection in DAP, and $c$ and $f$ are constants. The Gompertz model has been shown to predict the relationship between relative yield, as influenced by the length of the weed-free period (Hall et al., 1992; Knezevic et al., 2002). The model has the following form:

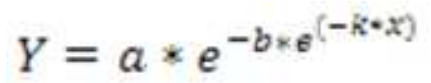

where $\mathrm{Y}$ is the relative yield, $\mathrm{a}$ is the yield asymptote or maximum yield in the absence of weed interference, band care constants, and $T$ is the length of the weed-free period after sugarcane planting in DAP. Goodness of fit was studied in terms of minimum root mean square error (RMSE) and by calculating the model efficiency index (EF). The EF was calculated as follows:

$\mathrm{EF}=1-\frac{\sum_{\mathrm{i}=1}^{\mathrm{n}}\left(\mathrm{Y}_{\mathrm{i}}-\overline{\mathrm{Y}_{1}}\right)^{2}}{\sum_{\mathrm{i}=1}^{\mathrm{n}}\left(\mathrm{Y}_{\mathrm{i}}-\overline{\mathrm{Y}}\right)^{2}}$

where $\mathrm{Y}_{\mathrm{i}}$ is the measured value for situation $i$, $\overline{\mathrm{Y}}_{1}^{-}$ $Y_{1}$ is the corresponding value calculated by the model and $\bar{Y}_{1}$ is the average of the $Y_{i}$ values. EF values range from 0 to 1 ; the nearer the value to 1 , the better the goodness of fit of the model.

The logistic equation (equation 1) was used to determine the beginning of the CPWC, and the Gompertz equation (equation 
2) was used to determine the end of the CPWC for acceptable yield loss levels (AYL) of $5 \%, 10 \%, 15 \%$ and $20 \%$.

Analysis of variance of weed biomass means, was performed using PROC GLM of SAS software. The level of significance is indicated by the least significant difference between the means (LSD) at 5\% probability. Additionally, the relationship between weed dry weight and the treatments was described using PROC REG in SAS (SAS Institute, 2002). To determine the type of relationship between weed dry weight and the treatments, an exponential equation (3) was fitted to the series of weed-free treatments (Sit and Costello, 1994; Mondani et al., 2011):

$$
Y=a * e^{b x}
$$

where, $\mathrm{Y}$ is the weed dry weight $\left(\mathrm{g} \mathrm{m}^{-2}\right), a$ and $b$ are constants of curve and $\mathrm{X}$ is the length of weed-free period (in DAP).

Schumacher's (1939) model, also used by Mondani et al. (2011), was fitted to the weedinfested treatments and weed biomass accumulation using the NLIN PROC of SAS (SAS Institute, 2002).

$$
Y=e^{a+b / x}
$$

where, $\mathrm{Y}$ is the weed dry weight $\left(\mathrm{g} \mathrm{m}^{-2}\right), a$ and $b$ are constants of curve and $\mathrm{X}$ is the duration of weed infested period (in DAP).

\section{RESULTS}

\section{Weed measurements}

Floristic diversity

Weed floristic diversity in Zuenoula is shown by Table 2 and Table 3. In Zuenoula, the weed flora of the field experiments is constituted of 93 species. These species were distributed into 32 families and 72 genera. The most representative botanical families, constituting $58 \%$ of the identified species, are Poaceae (8 species), Cyperaceae (3 species), Solanacaeae (3 species). The number of genera per family ranges between 1 and 8 .
The major weeds in Zuenoula were horse purslane (Trianthema portulacastrum L.), itchgrass (Rottboellia cochinchinensis (Lour.) Clayton), crowfootgrass (Dactyloctenium aegyptium (L.) Willd.), purple nutsedge (Cyperus rotundus L.), Brachiaria lata (Schum.) C.E. Hubb. Horse purslane (Trianthema portulacastrum L.) is the most abundant.

In Yamoussoukro, the weed flora of the field experiments was composed of 34 species. Table 4 shows the weed families, genera and species.

These species were distributed into 14 families and 28 genera. The most representative botanical families, constituting $62.5 \%$ of the identified species, are Poaceae (8 species), Cyperaceae (3 species), Euphorbiaceae (3 species), Tiliaceae (3 species), Fabaceae (3 species). The number of genera per family ranges between 1 and 8 . The dominant weed species were Mimosa pudica L., Brachiaria Griseb., Croton hirtus L'Hér., Spermacoce ruelliae DC., Dactyloctenium aegyptium (L.) Willd. and Ipomoea heterotricha Didr.

\section{Weed biomass evolution}

The analysis of variance revealed a significant effect $(\mathrm{p}<0.0001)$ of the imposed sets of weed interference on weed biomass. The season-long weedy treatment presents the highest weed biomass $(1866.57 \pm 79.16 \mathrm{~g})$. The analysis of variance also revealed that keeping the crop weed-free until 32 DAP provides the second highest weed dry weight $(1442.2 \pm 89.50 \mathrm{~g})$. Starting weed control at that date provoked only $22.74 \%$ reduction of weed biomass (compared to weedy treatment). Similarly, keeping sugarcane weed-free until 162 DAP induced $96.52 \%$ reduction of weed dry weight. On the contrary, when weeds were permitted to grow within the crop until 32 DAP weed biomass reduction is of $98.90 \%$ (compared to weedy treatment). That reduction is of $97.51 \%$ for allowing weeds to compete with sugarcane until 69 DAP. 
The parameters estimates, for the exponential and Schumacher's model fitted to the data, are shown in Table 5.

The results on weed biomass, as influenced by the weedy and weed-free treatments, are shown in Figure 1.

Total weed dry weight increased with increasing duration of weed-infested period. In contrast, total weed dry weight in all growing season, decreased with increasing duration of weed-free period (Figure 1).

\section{Critical period for weed control in sugarcane}

In intensive conditions (Zuenoula) and non-intensive conditions (Yamoussoukro) the yields of sugarcane declined with increasing duration of weed presence (Figures 2 and 3). Average yields were reduced with prolonged delays in weed removal at two locations. Conversely, the mean of sugarcane weight increased with increasing duration of weedfree period in both cropping systems (Figures 2 and 3 ).

The presence of weeds during the entire growing season decreased sugarcane yield more than $50 \%$ and $61 \%$ in intensive and non-intensive cropping systems, respectively.

Besides that, the average yield of sugarcane in the weed-free treatments was $115.8 \pm 4.64 \mathrm{t} / \mathrm{ha}$ in intensive and $32.86 \pm 4.51$ $\mathrm{t} / \mathrm{ha}$ in non-intensive cropping systems, respectively. On the contrary, weed interference during the entire growing season provoked a sugarcane yield of $57.03 \pm 5.19 \mathrm{t} / \mathrm{ha}$ in Zuenoula and $12.77 \pm 5.02$ t/ha in Yamoussoukro.

In both locations, the treatments (timing of weed removal and length weed-free period) have a significant effect on the relative yield ( $\mathrm{p}<0.0001$ ), indicating that regression analysis may be appropriate. The parameters estimates, of the three-parameter logistic and the Gompertz model (Equations 1 and 2) fitted to the data, are shown in Table 6.

In the intensive production system of Zuenoula, the beginning of the CPWC was 28
DAP at 5\% AYL, 30 DAP at 10\% AYL, 32 DAP at $15 \%$ AYL and 34 at $20 \%$ AYL (Table 7 ). The end of the CPWC was $117 \mathrm{DAP}$ at $5 \%$ AYL, 93 DAP at $10 \%$ AYL, 75 DAP at $15 \%$ and 59 DAP at 20\% AYL (Table 7). The end of the CPWC increased as the AYL decreased from $20 \%$ to $5 \%$ (Table 7, Figure 2). Results showed that in the beginning of the growing season weeds have no economic damage. Thus, to provide less than 5\% yield losses, there is no need to control weeds before 28 days. Similarly, weed control achieved after 117 days cannot provoke yield losses greater than $5 \%$. Thus, it is recommended that after this period, farmers do not apply weed control methods (in similar field conditions). After the CPWC, sugarcane dominates on weeds because of its canopy extension and high competitiveness. The length of the CPWC was 90, 64 days for 5 and 10\% AYL, respectively. That length of CPWC was 44 and 26 days for 15 and $20 \%$ AYL, respectively.

In non-intensive conditions of Yamoussoukro, using a 5\%, 10\%, 15\% and $20 \%$ AYL, gives a beginning of CPWC of 38 , 39 and 40 DAP (Table 7). The end of the CPWC was 163 DAP at 5\% AYL, 112 DAP at $10 \%$ AYL, $99 \mathrm{DAP}$ at $15 \%$ and $91 \mathrm{DAP}$ at $20 \%$ AYL (Table 7). The end of the CPWC increased as the AYL decreased from $20 \%$ to $5 \%$ (Table 7, Figure 3). These results also revealed that in the beginning of the growing season weeds have no economic damage. As a result, to provide less than $5 \%$ yield losses, there is no need to control weeds before 38 days. Likewise, weed control achieved after 163 days cannot provoke yield losses greater than $5 \%$. Thus, it is recommended that after this period, farmers do not apply weed control methods (in similar field conditions). After the CPWC, sugarcane dominates on weeds because of its canopy extension and high competitiveness. The length of the CPWC was 126 and 74 days for 5 and $10 \%$ AYL, respectively. That length of CPWC was 60 and 52 days for 15 and 20\% AYL, respectively. 
Table 1: The rating scale for weeds (Le Bourgeois, 1993).

\begin{tabular}{ll}
\hline Index & Meaning \\
\hline 5 & Individuals covering more than $3 / 4$ of the sampled area, some abundance \\
4 & Individuals covering from $1 / 2$ to $3 / 4$ of the sampled area, some abundance \\
3 & Individuals covering $1 / 4$ to $1 / 2$ of the sampled area, some abundance \\
2 & Very abundant individuals, covered $1 / 20$ of the sampled area \\
1 & Rare individuals, less abundant or abundant but weak covering \\
\hline
\end{tabular}

Table 2: Weed flora families in the sugarcane field in Zuenoula.

\begin{tabular}{|c|c|c|}
\hline Family & Genus (number) & Species (number) \\
\hline Aizoaceae & 1 & 1 \\
\hline Amaranthaceae & 3 & 3 \\
\hline Araceae & 1 & 1 \\
\hline Asteraceae & 10 & 10 \\
\hline Bombacaceae & 1 & 1 \\
\hline Caesalpiniaceae & 2 & 2 \\
\hline Capparidaceae & 1 & 1 \\
\hline Commelinaceae & 1 & 3 \\
\hline Convolvulaceae & 1 & 3 \\
\hline Cucurbitaceae & 1 & 1 \\
\hline Cyperaceae & 3 & 5 \\
\hline Dioscoreaceae & 1 & 2 \\
\hline Euphorbiaceae & 5 & 9 \\
\hline Fabaceae & 4 & 4 \\
\hline Loganiaceae & 1 & 1 \\
\hline Molluginaceae & 1 & 1 \\
\hline Malvaceae & 3 & 4 \\
\hline Moraceae & 1 & 1 \\
\hline Nyctaginaceae & 1 & 2 \\
\hline Passifloraceae & 1 & 1 \\
\hline Poaceae & 14 & 17 \\
\hline Portulacaceae & 2 & 2 \\
\hline Rosaceae & 1 & 1 \\
\hline Rubiaceae & 2 & 3 \\
\hline Solanaceae & 2 & 6 \\
\hline Sterculiaceae & 1 & 1 \\
\hline Tacaceae & 1 & 1 \\
\hline Tiliaceae & 1 & 1 \\
\hline Ulmaceae & 1 & 1 \\
\hline Urticaceae & 1 & 1 \\
\hline Verbenaceae & 2 & 2 \\
\hline Zygophyllaceae & 1 & 1 \\
\hline Total & 72 & 93 \\
\hline
\end{tabular}


Table 3: Abundance-dominance average of main weeds in Zuenoula.

\begin{tabular}{llc}
\hline Species & Family & AD average \\
\hline Trianthema portulacastrum L. & Aizoaceae & 5 \\
Cyperus rotundus L. & Cyperaceae & 3 \\
Rottboellia cochinchinensis (Lour.) Clayton & Poaceae & 2 \\
Brachiaria lata (Schum.) C.E. Hubb. & Poaceae & 2 \\
Dactyloctenium aegyptium (L.) Willd. & Poaceae & 3 \\
\hline
\end{tabular}

Table 4: Weed flora families in the sugarcane field in Yamoussoukro.

\begin{tabular}{lcc}
\hline Family & Genus (number) & Species (number) \\
\hline Poaceae & 8 & 7 \\
Fabaceae & 4 & 4 \\
Caesalpiniaceae & 2 & 1 \\
Mimosaceae & 3 & 2 \\
Tiliaceae & 3 & 2 \\
Euphorbiaceae & 3 & 2 \\
Cyperaceae & 2 & 2 \\
Asteraceae & 1 & 1 \\
Solanaceae & 2 & 2 \\
Rubiaceae & 1 & 1 \\
Convolvulaceae & 2 & 1 \\
Passifloraceae & 1 & 1 \\
Loganiaceae & 1 & 1 \\
Malvaceae & 1 & 1 \\
\hline Total & $\mathbf{3 4}$ & $\mathbf{2 8}$ \\
\hline
\end{tabular}

Table 5: Parameters values for response curves based on exponential model (a) and Schumacher's (1939) model (b).

\begin{tabular}{|c|c|c|c|c|}
\hline \multicolumn{2}{|c|}{ Equation model } & \multirow{2}{*}{$\begin{array}{c}\mathbf{a} \\
4084.97\end{array}$} & \multirow{2}{*}{$\frac{\mathbf{b}}{-0.02525}$} & \multirow{2}{*}{$\begin{array}{c}\mathbf{R}^{\mathbf{2}} \\
0.9467\end{array}$} \\
\hline (a) & $Y=$ & & & \\
\hline (b) & $\boldsymbol{Y}=$ & 8.1328 & -215.8 & 0.988 \\
\hline
\end{tabular}




\section{K.. B. J. KOUAMÉ et al. / Int. J. Biol. Chem. Sci. 8(5): 2244-2257, 2014}

Table 6: Parameters estimates of the three parameter logistic model used to determine the critical timing of weed removal and the Gompertz model used to determine the critical weed-free period for sugarcane in 2002 and 2011 (Equations 1 and 2).

\begin{tabular}{|c|c|c|c|c|c|c|c|c|c|c|c|}
\hline \multirow[t]{2}{*}{ Location } & \multirow[t]{2}{*}{ Year } & \multicolumn{5}{|c|}{ Gompertz } & \multicolumn{5}{|c|}{ Logistic } \\
\hline & & $\mathbf{a}$ & b & $\mathbf{k}$ & RMSE & $\mathbf{E F}$ & c & d & f & RMSE & $\mathbf{E F}$ \\
\hline Zuenoula & 2002 & 108.78 & 0.7144 & 0.01422 & 4.14 & 0.389 & 0.3581 & 29.5722 & 3.0284 & 4.13 & 0.997 \\
\hline Yamoussoukro & 2011 & 95.3768 & 22.0326 & 0.05277 & 3.38 & 0.982 & 1.3177 & 40.0730 & 1.9233 & 3.25 & 0.971 \\
\hline
\end{tabular}

RMSE: root mean square error EF: model efficiency index

Table 7: Critical period for Weed Control (CPWC) for sugarcane determined through Logistic and Gompertz equations at four acceptable yield losses (AYL) during two years and expressed in days after (DAP).

\begin{tabular}{lcccc}
\hline \multirow{2}{*}{ AYL } & \multicolumn{2}{c}{ Beginning of CPWC (DAP) } & \multicolumn{2}{c}{ End of CPWC (DAP) } \\
\cline { 2 - 5 } & $\mathbf{2 0 0 2}$ & $\mathbf{2 0 1 1}$ & $\mathbf{2 0 0 2}$ & $\mathbf{2 0 1 1}$ \\
\hline $5 \%$ & 28 & 38 & 117 & 163 \\
$10 \%$ & 30 & 39 & 93 & 112 \\
$15 \%$ & 40 & 75 & 99 \\
$20 \%$ & 32 & 40 & 59 & 91 \\
\hline
\end{tabular}



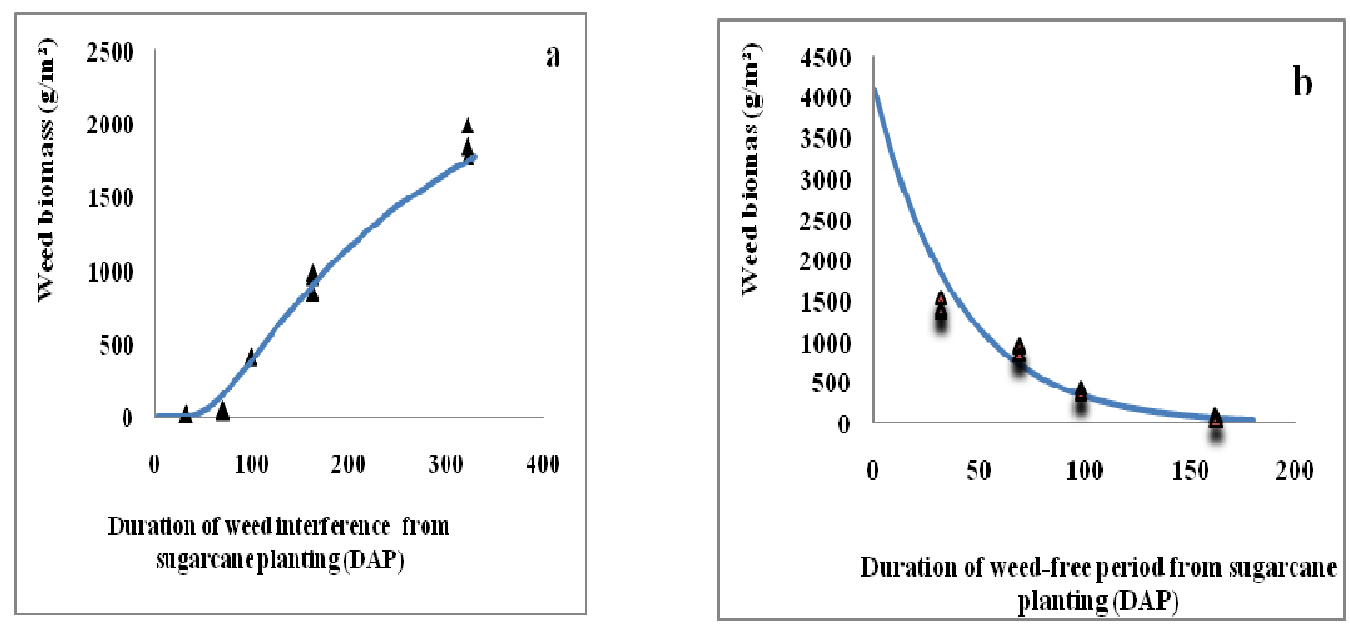

Figure 1: Weed biomass as a function of lengths of (a) weed interference and (b) and weed-free duration from sugarcane planting date in Yamoussoukro. Symbols indicate observed data (see Table 5 for coefficients).

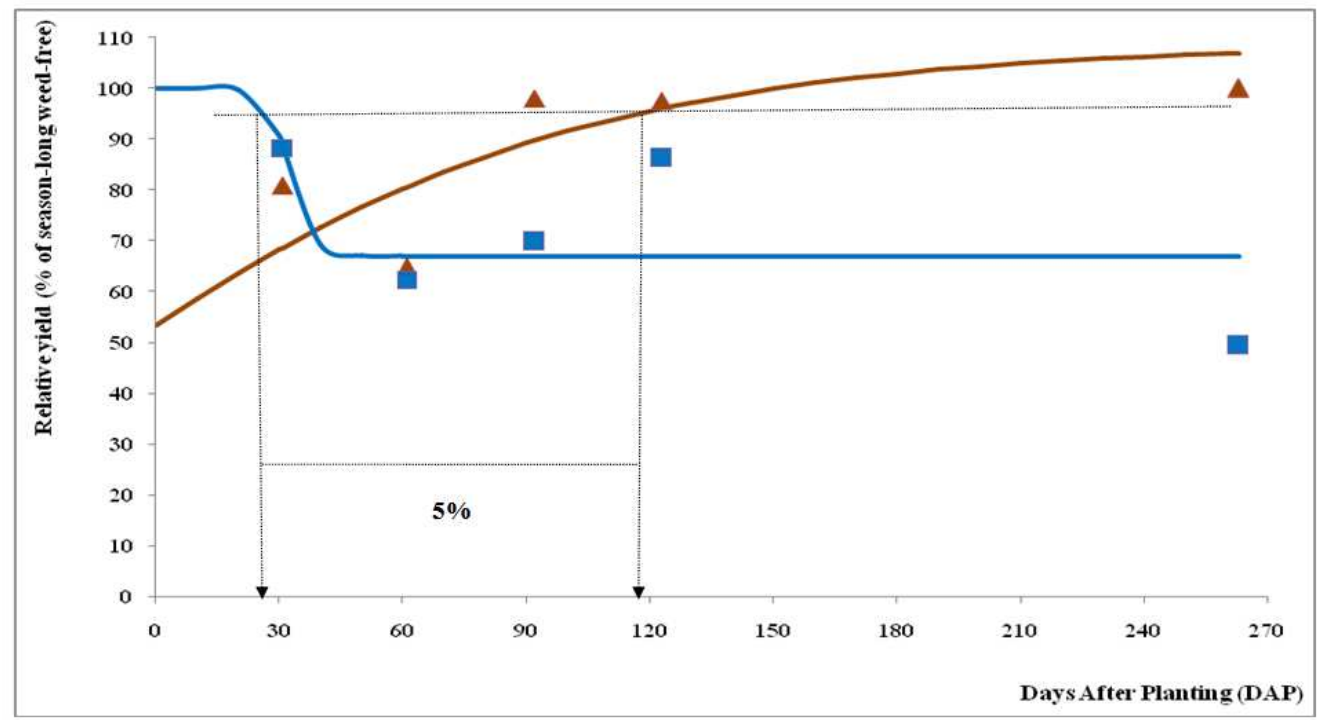

Figure 2: Effect of weed interference on total yield of sugarcane. Increasing duration of weed interference $(\boldsymbol{\bullet})$ and fitted curves as calculated by the logistic equation; increasing weed-free period $(\boldsymbol{\Delta})$ and fitted curves as calculated by the Gompertz equation. Dots represent observed data averaged over 2001-2002. Horizontal dashed lines indicate the 5\%, $10 \%, 15 \%$ and $20 \%$ acceptable yield loss levels used to determine the CPWC, whereas vertical dashed lines indicate the beginning and end of CPWC. Parameters for fitted curves are given in Table 6. 


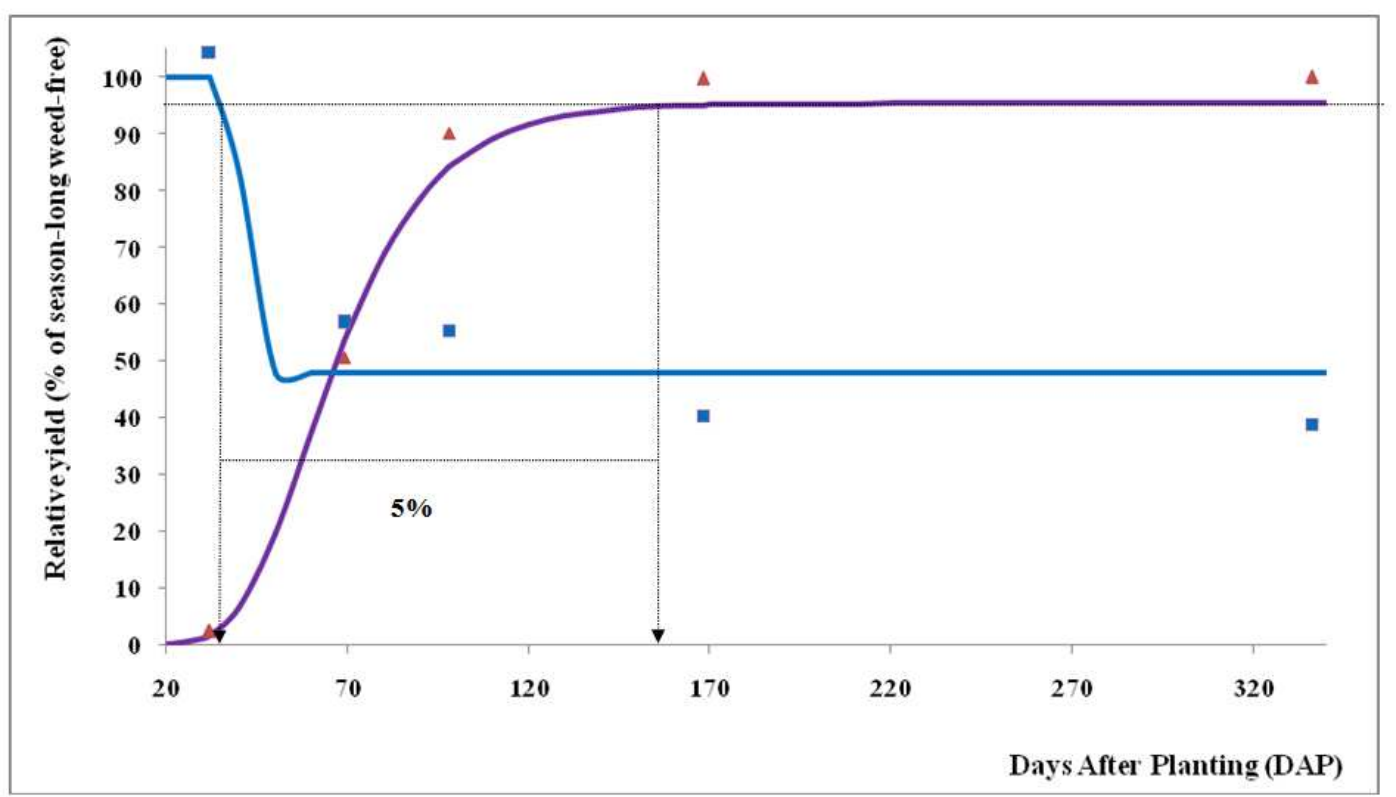

Figure 3: Effect of weed interference on total yield of sugarcane. Increasing duration of weed interference (-) and fitted curves as calculated by the logistic equation; increasing weed-free period $(\boldsymbol{\Lambda})$ and fitted curves as calculated by the Gompertz equation. Dots represent observed data averaged over 2010-2011. Horizontal dashed lines indicate the 5\%, $10 \%, 15 \%$ and $20 \%$ acceptable yield loss levels used to determine the CPWC, whereas vertical dashed lines indicate the beginning and end of CPWC. Parameters for fitted curves given in Table 6.

\section{DISCUSSION}

\section{Weed species composition and biomass evolution}

According to Akobundu (1987), 10 families comprise the most species considered as «major world weeds». Those families are Euphorbiaceae, Malvaceae, Asteraceae, Poaceae, Cyperaceae, Convolvulaceae, Fabaceae, Polygonaceae, Amaranthaceae and Solanaceae. Among those 10 aforementioned families, 4 dominant families were found during our field experiment: Euphorbiaceae, Poaceae, Cyperaceae, and Fabaceae. These results are also close to those of Aman-Kadio et al. (2004), who noted the dominance of 5 families (Euphorbiaceae, Asteraceae, Poaceae, Cyperaceae, Rubiaceae) in the crops' weed flora. Generally, the floristic diversity of the experiments shows a likeness with the ivorian flora (Aké-Assi, 2002) characterized by 7 dominant families of Angiosperms that are Leguminoseae, Rubiaceae, Poaceae, Orchidaceae, Cyperaceae, Euphorbiaceae and Asteraceae.
Total weed dry weight in all growing season, decreased with increasing duration of weed-free period. This phenomenon is in agreement with Mondani et al. (2011) who stated that total dry weight of weeds was the highest in the unweeded control. It is followed by weeding at 162 days after planting. As the total weed biomass reveals weeds growing ability and is a good predictor of their competitive ability against crops (Sarwar, 1994), the competitive ability of plants for resources such as light, nutrients and soil water is linked to biomass allocation (Aerts et al., 1991). For Tilman (1988), light interception and soil nutrients absorption are proportional to leaves and roots biomass respectively because resources are captured by plants to produce dry matter that is redistributed to various organs (stems, roots, leaves, fruits). Consequently, weeds emerging earlier in the growing season of sugarcane are the ones that will have the greatest biomass. Therefore, they have an important role in time 
of weed removal and choosing an appropriate method for weed control in sugarcane fields.

\section{Critical period for weed control in sugarcane}

Sugarcane yields decreased in Yamoussoukro. In Zuenoula, yields varied from $57.03 \pm 5.19 \mathrm{t} / \mathrm{ha}$ to $115.82 \pm 4.64 \mathrm{t} / \mathrm{ha}$ while in Yamoussoukro they ranged from $0.80 \pm 0.244 \mathrm{t} / \mathrm{ha}$ to $34.32 \pm 5.02 \mathrm{t} / \mathrm{ha}$. The highest yield in Yamoussoukro was less than the lowest yield (weedy control) in Zuenoula. The high yielding in Zuenoula can be explained by the intensive management of sugarcane at that location (fertilization, irrigation, pest management). In fact, according to Anonymous (1985), comparatively to rainfed sugarcane, the irrigation increases the yields of $30 \%$. In the North of Côte d'Ivoire (Ferkessedougou) for instance, it permits to double and even to multiply by 3 the yields, compared to those in rainfed crop (Diomande, 1989). According to Péné (1999), water is the first limiting factor for sugarcane yield in Côte d'Ivoire.

The results of the experiments suggest that increasing the duration of weed interference decreased sugarcane yield significantly. In Zuenoula in 2002, the CPWC was from 28 to 117 DAP to prevent yield losses of $5 \%$. This period to prevent yield losses of 10, 15 and $20 \%$ was from 30 to 93 DAP, from 32 to 75 DAP and from 34 to 59 DAP, respectively. In 2011, at the experimental farm of National School of Agronomy of Yamoussoukro, the CPWC ranged from 38 to 163 to prevent yield losses of $5 \%$. This period to prevent yield losses of $10 \%, 15 \%$ and $20 \%$ ranged from 39 to 112 , from 40 to 99 DAP and from 40 to 91 DAP, respectively. Results from this experiment suggest that weed control should be carried out between 28 and 117 DAP in intensive conditions and between 38 and 163 in nonintensive conditions to provide maximum sugarcane yield. The cultural practices and environmental conditions of the two locations modified the CPWC in sugarcane. In fact, previous research has suggested that the exact outcome of crop-weed interference is dependent on many site-specific factors, particularly the availability of essential nutrients (Di Tomaso, 1995; Tollenaar et al., 1994; Vengris et al., 1955; Weaver et al., 1992). Therefore, nutrient management has been identified as a likely strategy for weed management (Walker and Buchanan, 1982). In Zuenoula, because of the intensive production conditions, canopy closure is earlier than in Yamoussoukro. Knowledge of the CPWC and the factors that affect it is essential for making decisions on the appropriate timing of weed control and in achieving the efficient use of herbicides (Knezevic et al., 2002; Mulugeta and Boerboom, 2000).

In its early stages, sugarcane germinates and grows very slowly, while weeds show a rapid growth due to the lack of competition from the crop. If not checked timely, early tillering and growth of sugarcane is likely to be affected by weed competition. Singh et al. (1980) reported that critical period for weed control was between 30 and 120 days after planting sugarcane in Spring. Punzelan and Cruzz (1981) obtained maximum yield of cane when the crop was kept weed free from one to three months after planting, controlling weeds for longer periods did not enhance yields. It was further observed that weeds competition for one month from planting had no adverse effect on cane yields, whereas competition for two months reduced yield by $15 \%$ and for the whole season by $55 \%$. In India for example, it was reported that critical period of weed crop competition in sugarcane ranged between 27 and 50 days (Srivastava et al., 2003). Critical period of weed-crop competition was also found 45 days after sowing (Zafar et al., 2010).

\section{Conclusion}

The critical period for weed control represents the time during which weeds must be controlled to avoid an assigned level of 
crop yield loss, which is often $5 \%$. Difference in CPWC due to intensive and non-intensive cropping systems documented in this experiment highlights the need for a better understanding of the effects of environmental conditions (rainfall, solar radiation, wind speed, temperature) and intensification factors (irrigation, fertilisation) on crop-weeds competition for limited resources. The development of an Integrated Weed Management (IWM) System requires a deeper understanding of the behaviour of weeds in agro-ecosystems. The practical application of this study is that weeds must be controlled from 28 to 117 days and from 38 to 163 days after planting in intensive and non-intensive production systems, respectively, to prevent more than $5 \%$ unacceptable yield losses. If these critical periods for weed control are adopted by farmers and practitioners, they have the potential to influence their decision making on timing of POST herbicide application. And as Ivorian farmers usually tackle weed problems after weed emergence, these CPWC help them optimise POST herbicide doses.

\section{REFERNCES}

Aerts R, Boot RGA, Van Der Art PJM. 1991.

The relation between above and belowground biomass allocation patterns and competitive ability. Oecologia, 87: 551-559.

Aké-Assi L. 2002. Flore de la Côte d'Ivoire : catalogue systématique, biogéographie et écologie. II. Mémoires de Botanique systématique. Conservatoire et Jardin Botanique de Genève. Boisseria, 58.

Akobundu IU. 1987. Weed Sciences in tropics. Principles and Practices. Wiley, Chichester: UK.

Aman-Kadio G, Ipou IJ, Touré Y. 2004. La flore des adventices des cultures cotonnières de la région du Worodougou, au Nord-ouest de la Côte d'Ivoire. Agron. Afr,. 16(1): 1-14.
Anonymous. 1985. Rapport de l'Institut des Savanes. IDESSA. Comité technique élargi.

Braun-Blanquet J. 1932. Plant sociology. The study of plant communities (English translation of "pflanzensoziologie" by G. D. Fuller and H. S. Conard). University of Chicago: USA.

Cheema MS, Bashir S, Ahmad F. 2010. Evaluation of integrated weed management practices for sugarcane. Pak. J. Weed Sci. Res., 16(3): 257-265.

Di Tomaso J. 1995. Approaches for improving crop competitiveness through the manipulation of fertilization strategies. Weed Sci., 43: 491-497.

Diomande. 1989. La canne à sucre: les techniques culturales. Terres et Progrès, 76: 23-25.

Dudley TS, Edward PRJr, Lance TS. 2008. Weed Control in Sugarcane and the Role of Triazine Herbicides. In The Triazine Herbicides : 50 years Revolutionizing Agriculture, LeBaron HM, McFarland JE, Burnside OC (eds). Elsevier; 185-197.

Hall MR, Swanton CJ, Anderson G. 1992. The critical period of weed control in grain corn (Zea mays). Weed Sci., 40: 441-447.

Khan MZ, Bashir S, Bajwa MA. 2004. Performance of promising sugarcane varieties in response of inter-row spacing towards stripped cane and sugar yield. Pak. Sugar J., 19(5): 15-18.

Knezevic SZ, Evans SP, Blankenship EE, Van Acker RC, Lindquist JL. 2002. Critical period for weed control: the concept and data analysis. Weed Sci., 50: 773-786.

Le Bourgeois T. 1993. Les mauvaises herbes dans la rotation cotonnière au NordCameroun (Afrique): Amplitude d'habitat-Degré d'infestation-Phénologie. Thèse de doctorat, Université de Montpellier II, Montepellier, p. 249.

Mulugeta D, Boerboom CM. 2000. Critical time of weed removal in glyphosateresistant Glycine max. Weed Sci., 48: 3542. 
Marnotte P. 2000. La gestion de l'enherbement et l'emploi des herbicides dans les systèmes de culture en zone Soudano-sahélienne en Afrique de l'Ouest et du Centre. CIRAD-CA-GEC. AMATROP, p. 66.

Mondani F, Golzardi F, Ahmadvand G, Ghorbani R, Moradi R. 2011. Influence of weed competition on potato growth, production and radiation use efficiency. Not Sci Biol., 3(3): 42-52.

Péné CB. 199. Gestion de l'irrigation en culture cannière : stratégies pour optimiser l'efficience d'utilisation de l'eau dans les périmètres sucriers ivoiriens. $\mathrm{PhD}$ thesis, University of Abidjan-Cocody, Abidjan, p. 267.

Punzelan FL, De La Cruzz. 1981. Effect of duration of weed competition and weed control in sugarcane. Philippines J. Weed Sci., 8: 15-18.

Rajcan I, Swanton CJ. 2001. Understanding maize-weed competition: resource competition, light quality, and the whole plant. Field Crops Res., 71: 139-150.

Richard Jr EP. 1996. Efforts to control bermudagrass (Cynodon dactylon) in sugarcane grown in Louisiana. Proc. Int. Soc. Sugarcane Technol., 22(2): 115-122.

Sarwar M. 1994. Studies on wild oat interference, nutrient competition and economic threshold level in wheat. $\mathrm{PhD}$ thesis, Department of Agronomy. University of Agriculture, Faisalabad.

SAS Institute. 2002. SAS 9.00. SAS Institute Inc., Cary, NC, USA.

Schumacher FX. 1939. A new growth curve and its application to timber-yield studies. J. For., 37: 819-820.

Singh G, Pant PC, Bhan VM. 1980. Studies on the critical period of weed control in spring planted sugarcane. Indian J. Weed Sci., 12(2): 120-124.

Sit V, Costello MP. 1994. Catalog of Curves for Curve Fitting. Biometrics Information Handbook Series No. 4. Ministry of Forests BC: Victoria Canada.
Srivastava TK, Singh AK, Srivastava SN. 2003. Critical period of weed competition in sugarcane ratoon. Indian J. Weed Sci., 34 (3-4): 320-321.

Swanton CJ, Weise SF. 1991. Integrated weed management: the rationale and approach. Weed Technol., 5: 648-656.

Tilman D. 1988. Plant Strategies and the Dynamics and Structure of Plant Communities. Princeton University Press: Princeton, New Jersey.

Tollenaar MSP, Nissanka AA, Weise SF, Swanton CJ. 1994. Effect of weed interference and soil nitrogen on four maize hybrids. Agron. J., 86: 596-601.

Uremis I, Uludag A, Ulger AC, Cakir B. 2009. Determination of critical period for weed control in the second crop corn under Mediterranean conditions. Afri. J. Biotech., 8(18): 4475-4480.

Vengris J, Colby WG, Drake M. 1955. Plant nutrient competition between weeds and crops. Agron. J,. 47: 213-216.

Walker RH, Buchanan GA. 1982. Crop manipulation in integrated weed management systems. Weed Sci., 30(1): $17-24$.

Weaver SE, Kropff MJ, Groeneveld RW. 1992. Use of ecophysiological models for crop-weed interference: the critical period of weed interference. Weed Sci., 40: 302307.

Zafar M, Tanveer A, Cheema ZA, Ashraf M. 2010. Weed-crop competition effects on growth and yield of sugarcane planted using two methods. Pak. J. Bot., 42(2): 815-823.

Zimdahl RL. 2004. Weed-Crop Competition: A Review (2nd edn). Blackwell Publishing: Ames. 